\title{
The Use of Exoneration Clausules as a Legal Protection for Notary
}

\author{
Fenny Octavia*, HK Martono, Tundjung Herning Sitabuana, Gunawan Djajaputra \\ Universitas Tarumanagara-Jakarta
}

Received: 20/04/2020

Accepted: 30/09/2020

Published: 20/12/2020

\begin{abstract}
This article aims to examine the use of exoneration clauses in a Notary deeds, as a new form of legal protection for Notaries in Indonesia. The research method used is juridical normative, with data collection techniques in the form of literature study of primary and secondary legal materials, and supported by interviews in support of the two legal materials. The results showed that it is possible to include an exoneration clause in a Notary deed, even though the Notary is not a party to the deed, the Notary can include the exoneration clause for his/ her own benefit. The exoneration clause as a self-protection effort carried out by a Notary, is a form of legal protection. In addition to functioning as an initial warning to the parties in the agreement, with this clause if there is an individual who states/ gives something that is untrue, then law enforcement officials can immediately take action against these parties without involving the Notary any further.
\end{abstract}

Keywords: Exoneration clause, Legal protection, Notary, Legal profession

\section{Introduction}

One form of state service to the public is by providing facilities to the public to obtain evidence or legal documents related to civil law. The authority for this purpose is given by the State to public officials who's professions are known in Indonesia as the Notary. In its development, Notaries have played a very big role in supporting the wheels of the national economy, structuring non-governmental organizations and political parties [1]. This is in line with the start of Indonesia entering the era of the Industrial Revolution 4.0, which is clearly seen by the application of a large-scale and comprehensive internet network system in almost all sectors to facilitate access to internal information in Ministries and agencies. The purpose of this digital bureaucracy is of course to simplify business processes to make them easier, faster and cheaper. So that Notaries are required to play an active role in supporting Government policies in electronically integrated services, in their efforts to make Indonesia 4.0.

Even though a Notary has been careful and in accordance with the statutory regulations in carrying out his/ her job duties, can still face legal challanges that can bring him/ her to be examine by law enforcement officials, whether it is an investigators, a public prosecutors, or a judge, as a requirement for the sake of the ongoing judicial process. Based on data obtained from the Central Board of the Indonesian Notary Association, up until 2016 the number of Notaries sentenced to imprisonment were 137 Notaries [2]. However, there are many cases in which the plaintiffs scrutinizing for faults of the Notary for the mere purpose of profiteering from the case. Infact, this is

Corresponding author: Fenny Octavia, Universitas Tarumanagara-Jakarta, E-mail: admin@knfo.co.id what is detrimental to the Notary both morally and materially.

Article 65 of the Law on Notary Position emphasizes that Notaries are considered to be carrying out personal and lifelong duties so that there is no time limit for accountability, because of this, the inherent responsibility is stuck to the former Notary wherever that he/ she may be [3]. This article has strengthened the Notary as a legal profession who needs to be legally protected in his/ her position as a profession, not only as a Notary, but also as a person. The Law on Notary Position has provided legal protection, however it is deemed insufficient to provide protection for the Notaries. In reality, there are still summons to Notaries by law enforcement officials, even by agencies/ institutions for things that are sometimes irrelevant. The essence of an authentic deed is sufficient to provide evidence without the need to present a Notary who made the deed. Even in the event that the Notary has carried out his duties in accordance with the laws and regulations, it is not uncommon for the Notary to become a defendant or co-defendant accompanied by a lawsuit for compensation.

In this study, the authors tried to adopt an exoneration clause as a form of legal protection for Notaries because in reality there are problems arrises from the use of the exoneration clause. Either because of the basis for the loading of the exoneration clause itself on the notary deed or in terms of legal protection given to the use of the exoneration clause. The relevance of the Notary's use of the exoneration clause as a legal protection measure even though that the Notary is not a party to the deed he/ she has made. However, the Notary can still include the exoneration clause in the deed of the parties. In addition, the effectiveness and feasibility of their use remains a matter of debate in practice. Notaries who carry out their positions in accordance with their functions provide strong evidence needed by the public, by deliberately using the exoneration clause he/ she prevent themselves from fulfilling their obligations. If this is 
the case in current practice, the function of a Notary cannot be fully implemented because it seems as if the Notary has released themself from his/ her obligations and responsibilities, thus it can be said that there is no guarantee of legal certainty.

Studies on exoneration clauses and legal protection measures has been carried out by several authors, however no studies has been carried out on exoneration clauses as a means of legal protection for Notaries. Studies on legal protection for Notaries that have been carried out by several researchers including Lumaria stated that Notaries must be protected in relation to the position they carry out, for the interests of the parties regarding the authentic deed they make, this form of protection is contained in the Law on the Position of Notary [4]. Furthermore, according to Erdi, the mechanism for the use of rights and obligations of a Notary refusal in terms of maintaining the confidentiality of the deed has received approval from the Notary Honorary Council to state that the deed is true of the person in question, but when it comes to content, it is appropriate for the Notary to exercise his right of denial [5].

Studies on exoneration clauses that have been carried out by several researchers include Nizla Rohaya, who further concluded that there is a prohibition on the use of standard clauses containing exoneration clauses for some business entities by Law No. 8 of 1999 concerning Consumer Protection (UUPK) gives the impression that the form of prohibition on the use of standard agreements is considered to greatly hinder economic activity, even though this is not the case [6]. In contrast to the studies conducted by Muhammad Saiful Rizal who examined the form of legal protection of personal data for consumers against exoneration clauses in online transportation, it is divided into preventive and repressive legal protection. However, on a civil basis in the UUPK it becomes null and void by law, so business entities must revise the standard agreement containing the exoneration clause and compensate for losses incurred by the consumers [7].

Based on the description of the studies above, it can be seen that there is a significant difference with this study, namely that even though it examines legal protection, the studies are carried out separately, there is no combination of the studies between the exoneration clause and legal protection of Notaries. Even the exoneration clause is positioned as a form of threat that causes injustice due to an unbalanced form of obligation and responsibility. Apart from that, the forms of legal protection discussed are those that already exist which are stated in the Law on Notary's position. In contrast to this studies, where the exoneration clause is placed as an effort to provide legal protection and this form of legal protection has not been regulated in the Law on Notary's position. Study on the exoneration clause that is used as a measure of legal protection for notaries related to the deed they have made can be ascertained that it has never been done.

In this regard, it is necessary to conduct study to determine the basis for loading the exoneration clause in the Notary deed and how the exoneration clause can provide legal protection for the Notary, so that the Notary in carrying out his/ her duties in accordance with the mandate and function based on the Law of Notary's position without any worry or anxiety. This is not to protect Notaries who are in the wrong or abuse their authority, but solely to protect Notaries who have carried out their duties properly and earnestly, of course this will also provide justice, especially for parties who use the services of Notaries and for
Notaries his/ herself. Notaries who carry out their duties in peace, their benefit can be felt by the business world and society.

\section{Research Methods}

The method used in the this study is normative juridical research method. Normative legal research is legal study that places law as a norm system building [8]. The specifications of this studies are descriptive analytical study, prescriptive study, and exploratory study. Furthermore, what is meant by prescriptive study, according to Prasetyo Hadi Purwandaka as quoted by Moh Nazir, is "a study to obtain suggestions and ideas in dealing with certain problems" [9]. This is not different from the opinion of Soerjono Soekanto who said that prescriptive study is "a study aimed at getting suggestions for solving certain problems" [10].

The definition of explorative study is "a study that aims to explore broadly about the causes or things that influence the occurrence of something" [11]. Exploratory study is study that aims to map an object relatively deeply or in other words exploratory study is a study that is conducted to find causes or things that influence the occurrence of something and is used when we do not know exactly and specifically about the object of our study. This study is used because the use of the exoneration clause as a means of legal protection to Notaries is a new thing, a new form of legal protection for Notaries.

The only source of normative legal study is secondary data. Secondary data consists of primary legal materials; secondary legal materials and tertiary legal materials [12]. In addition to secondary data in the form of the three legal materials above, according to Mukti Fajar, one of the materials used as a complement to legal materials is by conducting interviews in order to obtain data related to research [8]. It is different from previous studies which only conducted literature studies without any interviews. The interview in this case complements the existing primary and secondary legal materials.

\section{Literature Review 3.1 Exoneration Clause}

In the Kamus Besar Bahasa Indonesia (Indonesian Dictionary) [13] defines that "an exoneration clause is a clause included in an agreement whereby one party avoids fulfilling its obligations by paying full or limited compensation, which occurs due to broken promises or unlawful acts.

In Law Number 8 of 1999 concerning Consumer Protection, the term exoneration clause itself is not found, it does exist is the term "standard clause". Article 1 point 10 defines standard clauses as "rules or conditions and conditions that are prepared and determined unilaterally by a business entity as outlined in a binding document/ agreement and must be fulfilled by consumers." What this emphasized is the one-sided manufacturing procedure, not the content. In fact, the definition of an "exoneration clause" does not only question the manufacturing procedure, but also its content which transfers the responsibilities of business entities. In simple terms, this exoneration clause is defined as a clause transferring obligations/ responsibilities in the agreement. This clause can occur at the will of one of the parties as outlined in the agreement individually or en masse [14]. 
Treitel defines the exoneration clause as " a clause excluding or limiting liability", which translates as "a clause that eliminates or limits responsibility" [15]. Barnes calls it the exculpatory clause. The Exculpatory Clause according to Barnes is " a provision in a contract that attempts to relieve one party to the contract from liability for the consequences of his or her own negligence " [16]. Furthermore, Sutan Remy Sjahdemi [17] states that the existence clause is a clause that aims to release or limit the responsibility of one party to the lawsuit of the other party in the event that the person concerned does not or does not properly carry out his/ her obligations as stipulated in the agreement. In line with the opinion of Sutan Remy Sjahdemi, Munir Fuady [18], argues that the existence clause is a clause in a contract that frees or limits the responsibility of a party in case of default, whereas according to law, this responsibility should be borne by the individual.

R.H.J. Engels mentions that there are three juridical forms of the agreement with the exoneration clause, namely liability for legal consequences, limited or waived own obligations, the terms of release by one of the parties being charged with assuming other responsibilities that may exist for losses incurred or suffered by a third party [19]. From the various opinions above, what is meant by an exoneration clause is a clause that is used with the aim of basically to release or limit the liability of one party to the lawsuit of the other party, in the event the individual concerned does not or does not properly carry out his/ her obligations stipulated in the agreement.

\subsection{Notary}

According to the Kamus Besar Bahasa Indonesia (Indonesian Dictionary) [20], a Notary has the meaning of being authorized by the government based on an appointment (in this case, the Ministry of Law and Human Rights) to ratify and witness various agreements, wills, deeds, and so on. Based on its history in Indonesia, a Notary is a State official / or public official who can be appointed by the State to carry out State tasks in legal services to the public in order to achieve legal certainty as an authentic deed-making official in matters of a civil nature [21]. The definition of a Notary as referred to in Article 1 number 1 of Law Number 30 of 2004 concerning the Position of Notary which has been amended by Law Number 2 of 2014 concerning Amendments to Law Number 30 of 2004 concerning the Position of Notary (hereinafter referred to as Law Notary Position Law), states that "Notary is a public official who is authorized to make authentic deeds and has other powers as referred to in this Law or based on other Laws".

A Notary basic purpose is to prevent disputes, while a lawyer aims to resolve disputes that have arisen [22]. The moral values and ethical values of the Notary, lies in the service to the community which is carried out independently and impartially. This is carried out by the Notary as a life call that comes from the spirit of devotion to fellow humans for the sake of the public interest and is rooted in respect for human dignity in general and the dignity of Notaries in particular [23].

Product of Notary, namely deeds according to the Kamus Besar Bahasa Indonesia (Indonesian Dictionary) [20], have the meaning of a proof letter containing a statement (statement, acknowledgment, etc.) which is made according to the applicable regulations, witnessed and endorsed by a Notary or authorized government official. In Article 1868 of the Civil Code, an authentic deed is "a deed made in the form determined by law by/ or before a public official who is authorized for that purpose, at the place where the deed was made" [23].

The definition of a Notary Deed according to Article 1 point 7 of the Law on Notary Position, which states that "Notary Deed, hereinafter referred to as Deed, is an authentic deed made by or before a Notary according to the form and procedure stipulated in this law." Sudikno Mertokusumo defines a deed as follows "A deed is a letter as a sign of evidence, which contains events that form the basis of a right or agreement, which was made from the beginning on purpose for proof" [24].

\section{Results and Discussion}

In exercising its authority, especially in making authentic deeds, whether we realize it or not, in making the deeds, the Notary tries to limit liability to him/ herself as a profession that has the risk of facing legal problems. This self-protection effort has become a new form of legal protection, known as the exoneration clause. This can be seen from the examples of deeds distributed to participants in the congress of the Indonesian Notary Public Association as well as seminars held by Regional Administrators, Regional Administrators, and the Central Executive of the Indonesian Notaries Association, contained the contents of the exoneration clause.

Examples of self-protection clauses included in a Notary deed include, among others:

1. Whereas the parties state that the deed has been read to the parties and the parties sign it as a sign that they understand and understand the contents of the deed, so that if a dispute occurs both inside and outside the court, both civil and criminal will not involve the Notary in any way and form;

2. Whereas the parties state that all the words or statements of the parties written in this deed are true, if it becomes untrue, then it is the responsibility of the parties and will not involve the Notary;

3. Whereas the parties state that all letters or documents shown by the parties to the Notary and their contents included in this deed are true documents, if one day it is proven to be untrue then it becomes the full responsibility of the parties involved, and frees the Notary from legal consequences both civil and criminal.

So far, the form of legal protection for Notaries that already exists in Indonesia is only limited to what is in the laws and regulations as has been researched by previous researchers. Among other things, these legal protections are:

\subsection{Special permission to summon a Notary}

In Article 66 of the Law on the Position of Notary, it states that in the event that a Notary is summoned by an investigator, public prosecutor and court, he must first obtain permission from the Notary Honorary Council. The mechanism for summons of Notaries is regulated in Permenkumham Number 7 of 2016 concerning Notary Honorary Council, if it goes into the realm of pro-justice, the Notary Honorary Council will test whether or not the Notary should come to fulfil the summons.

\subsection{Rights of refusal}

Regarding the right of refusal, it is regulated in Article 16 paragraph (1) letter e and Article 4 paragraph (2) of the Law on the Position of Notary Public which states that the Notary has taken an oath/ promise, among other things "that I will keep the contents of the deed confidential and the information obtained in 
the execution of the position me". The obligation to keep confidential can be carried out by exercising the Right of Refusal, which is an exception to the provisions in Article 1909 of the Civil Code that everyone who is summoned as a witness is obliged to testify before the court.

Likewise, a agreement for summons of a Notary will be given if there is a criminal act by the Notary on Notary deed, in which case the Notary's right of refusal will be void when the Notary commits a criminal act. A criminal act which can be proven through the confession of witnesses.

So far, in carrying out their duties, the Notary has adhered to the principle that as long as the Notary carries out his/ her position according to the oath of office, the Notary is protected in carrying out his/ her job duties. Currently, this principle is no longer valid because of an extraordinary increase in crime and moral degradation. This can be seen by the inclusion of fingerprints as a formal form of deed, as stated in Article 16 paragraph 1 letter $\mathrm{C}$ of the Law on the Position of Notary Public, so parties who sign before a Notary also record fingerprints. The aim is that the parties present to sign the deed cannot deny their presence.

According to Dr. Winanto Wiryomartani, SH., MH., whom is a member of the Notary Central Supervisory Council, in practice, apart from the plantiff who sometimes have malicious intention, Notaries also face challenges from law enforcement officers which often occur when making a Notary deed, if the identity is given to a Notary Public false, then in the event of an investigation that follows, the Notary is considered to be a collaborator, and is subject to article 55 of the Criminal Code. The legal basis used by investigators when dealing with a notary if there is a legal problem is almost always linking it to article 55 of the Criminal Code, so it is almost certained that when there is a problem arises, the Notary will charge as collaborator by the plantiff. For example, those who use false identities, then the investigators immediately assume that the Notary is in collaboration [25].

This situation occurs because of differences in viewpoints and lack of understanding of law enforcement officers on the work ethic and duties of Notaries, where Notaries file formal filings while law enforcement officials are material, thus Notaries are also deemed to file filings materially. The Notary makes an authentic deed based on formal evidence and information from non-material parties.

The consideration for the inclusion of an exoneration clause is that existing legal protection measures are deemed insufficient to reduce and avoid the Notary's involvement in cases that occur between parties in the deed drawn up by the Notary. New legal protections derived from law are the last alternative because they take a long time to be realized. In the end, the use of the exoneration clause that became the choice of the Notary as an effort to protect the law.

The exoneration clause in this Notary deed is very much needed, especially regarding what legal protection can be provided against the provision of false data and information. So that when a party provide false data or information, the person responsible is that party. According to a member of the West Java Notary Honorary Council, Dr. H. Dhody AR Widjajaatmaja, SH, when the investigator found out that his/ her identity was false and his/ her identity was tested as well, it should have been processed based on article 263 of the Criminal Code against the suspect, not the Notary who was drawn as the perpetrator, because the Notary in making the deed did not have malicious intentions or mens rea elements to help the occurrence of criminal acts in that way [26]. The same thing was conveyed by the Head of the Land and Building Unit of the State Police of the Republic of Indonesia, the Metro Jaya Resort Metropolitan West Jakarta, Richardo Hutasoit, S.H., M.,H in his interview, he was uncertain that a person who is a Notary, highly educated, deliberately planned a crime together with his/ her client. Generally, if there is a violation, it is solely a violation of procedures and code of ethics that arises because of competition [27].

The existence of an exoneration clause in the Notary deed makes the parties responsible for themselves if the parties provided false information to the Notary, on the other hand the Notary as an official cannot be convicted in carrying out his position. In addition to the exoneration clause it is useful as an effort to protect the Notary, it provide certainty to the Notary, and the exoneration clause is also useful for early warnings which are expected to arouse awareness of the expectant which is expected to be used for prevention so that when party involved has mens rea from the beginning, the party will be detered at mentioned of the clause [26].

Notaries are not part of the parties but can use the exoneration clause in the deed because the Notary in carrying out his position must protect the community as stakeholders so that the deed he/ she makes is perfect. In addition, Notaries in carrying out their positions must protect themselves from problems that may arise. In its implementation, there are doubts regarding the use of the exoneration clause by the Notary, because the Notary is not a party to the agreement, but may include the exoneration clause in his act. Regarding this, there are several views regarding the basis for loading the exoneration clause, among others [25]:

a. Article 1338 of the Civil Code

The agreement made by the parties is binding as law. This means that the agreement is made by the parties in the form of a binding agreement and acts as an obligation.

b. Supreme Court Decision Number 702 / K / SIP / 1973 dated 5 September 1973

An authentic deed made by an authentic deed official is based on the formal evidence and statements of the parties as outlined in the form of an authentic deed, if there is a legal problem between the parties then all is the responsibility of the parties.

c. Article 1317 of the Civil Code

In an agreement it is permissible to request the stipulation of a promise for the benefit of a third party. Article 1317 paragraph (2) states that Whoever has promised that, may not withdraw it back, if the third party has stated that he intends to use it.

Although Article 1317 of the Civil Code regulates promises for the benefit of third parties, so that even though it is not a Party to the agreement, its interests can still be regulated, according to Dhody [21] in his interview Article 1317 of the Civil Code is not a legal basis for making an exoneration clause in the notary deed. Notary is not a party and must leave not as a party, because if the Notary is a party (even though the Notary's third party is still a party), the Notary's legal responsibility will have a different context in terms of his criminal and civil liability as a party with his legal responsibility as a Notary 
against criminal and civil charges. In connection with the Notary's position as a party to the engagement that they made in the form of an agreement, the exoneration clause merely reminds the parties not to provide false information.

If, the Notary is part of the party, if there is a default, then the Notary is involved as a party and becomes accountable. There are two types of presence of a Notary who is summoned by Law Enforcement Officials, namely presence in criminal cases and attendance in civil cases. Notary as a defendant, in case the Notary made an error. Notary as co-defendant in order to comply with the Supreme Court Decision Number 1642 / H / Pdt / 2005, namely in the case of a claim for lack of parties, causing the lawsuit to be rejected. Also, the defendant should not be sued for compensation, should there be a claim it is the fault of the party who sued. While a Notary is not a party so it cannot be made a defendant and as a co-defendant just so that the lawsuit is fulfilled, so that it is complete.

Although the existence of an exoneration clause at this time has not been able to minimize the summons made by law enforcement officials against the Notary Public, it can at least minimize the possibility of the Notary being made a defendant or co-defendant when false information provided is presented in the deed he/ she made. This certainly has a significant impact on the Notary profession, so that it can carry out its duties more calmly without any fear and produce the right legal products.

Summons to Notaries that have not been minimized are closely related to Investigators who act based on the Chief of Police Regulation number 14 of 2012 concerning procedures for how the police carry out legal proceedings. When receiving a public report, the police are bound by the SP2HP (Notification Letter on the Progress of Investigation Results) and are obliged to respond to the report, whether the report will be continued or stopped. If it is continued, there must be a report in the form of SP2HP regarding the actions that have been carried out by the investigator and the results.

In connection with the actions that have been taken by the Investigator, the presence of a Notary is deemed necessary by the Investigator in order to provide clarity. Head of Unit IDIK IV Assets and Buildings of the State Police of the Republic of Indonesia, Metro Jaya Resort Metro Bekasi Kota H. Untung Riswaji, S.H., M.H., MM., in the interview, investigators explained that in general, investigators were trying to obtain clarity if it was true that the signatures were signed before the Notary, if it was true, it meant that the people were really there, not fictitious. In this case the investigator will conclude that the deed is not a fake. Furthermore, an official report is made by the investigator and the Notary summons for requesting information is complete. However, if it is proven that a Notary is for example, in collusion with one of the parties, and states something that is not true in the deed, then the Notary is inviolation of Article 264 of the Criminal Code regarding false information in an authentic deed. In this case, Notaries can be punished and cannot be protected [28].

The presence of a Notary only to explain, authentic deeds based on law should be able to prove themselves without the presence of the Notary maker. In the law of proof, authentic deeds are the strongest and most fulfilling evidence, if someone denies the evidence, then he/ she is obligated to prove it. However, in reality the Notary must still be present to give testimony to confirm the deed he/ she has made [27]. This is back to the main problem, namely due to differences in the perspective of law enforcement officials who view notary deeds as only evidence in the form of letters as referred to in the Criminal Code. [28]. The current agreement between the Indonesian Notary Association and the Police is more about diplomatic relations, the technicality is how to understand the authentic deed as evidence or evidence related to the Criminal Procedure Code, in which the law has not been harmonized [26].

The point of view of thinking within the community itself, needs to be returned to the basis of the rule of law theory in which everyone is legally responsible, in all laws and regulations, including but not limited to the Criminal Code and the Criminal Code. Every human being in this country is responsible for their actions, thus giving false information in front of officials is a criminal act [27].

Protection of Notaries does not mean to create a profession that is immune to the law, but solely to protect the Notary but does not eliminate the Notary's obligations so as not to harm the parties who choose to use Notary services. The existence of the exoneration clause is a form of legal responsibility for the parties, because when they provide false information, the one who loses is a notary. As long as someone who appears before the Notary is in good health, not under interdiction or curator, not under pressure or abuse of circumstances, if all are fulfilled then there is no reason to deny everything stated in the deed. Include the contents of the exoneration clause.

The exoneration clause in the Notary deed can provide legal protection through the existence of the exoneration clause itself, where the contents of the exoneration clause are statements of the parties, in accordance with the theory of will, namely by taking into account the wishes of the parties facing to make an authentic deed in accordance with the law. related parties so as not to violate existing statutory provisions.

In this study, there are still limitations, namely research that has only been carried out among Notaries and some law enforcement officials, not among other related groups such as the public who use Notary services. Of course, it is interesting to see how the point of view of other circles has direct implications for the use of the exoneration clause as a form of legal protection for Notaries. However, this study is the first research that evaluates new forms of legal protection beyond what is contained in the Notary Office Act by adopting a method from a different field of science.

\section{Closing}

The existence of an exoneration clause at this time has not been able to minimize the summons made by law enforcement officials against Notaries, but at least it can reduce the possibility of a Notary being made a defendant or co-defendant when false information is found in the deed he makes. In the event of a summons by an investigator or a lawyer, the Notary is a form of legal protection provided, it is sufficient to show the clause and confirm that he has carried out his/ her duties in accordance with the Notary's oath of office. This certainly has a significant impact on the Notary profession, so that it can carry out its duties more calmly without any worries and produce the right legal products.

Research on the use of exoneration clauses among the public who use Notary services and other law enforcement officials such as prosecutors and judges is deemed necessary to harmonize thoughts and perspectives on how notaries work, so it 
is hoped that the use of exoneration clauses as an effort to protect the law against notaries can be maximized if the perspective the views of each party that intersect in harmony.

\section{Ethical issue}

Authors are aware of, and comply with, best practice in publication ethics specifically with regard to authorship (avoidance of guest authorship), dual submission, manipulation of figures, competing interests and compliance with policies on research ethics. Authors adhere to publication requirements that submitted work is original and has not been published elsewhere in any language.

\section{Competing interests}

The authors declare that there is no conflict of interest that would prejudice the impartiality of this scientific work.

\section{Authors' contribution}

All authors of this study have a complete contribution for data collection, data analyses and manuscript writing.

\section{References}

1 Hardum SE. Banyak Pengaduan Mengenai Pelanggaran Yang Dilakukan Notaris, [Internet]. 2019 Dec [cited 2020 Aug 1]. Available from: https://www.beritasatu.com/nasional/575615banyak-pengaduan-mengenai-pelanggaran-yang-dilakukan-notaris.

2 Alisyahdi DF. Menakar Peluang "Menang" Praperadilan Penetapan Tersangka Notaris, [Internet]. 2020.

3 Adjie H. Meneropong Khasanah Notaris dan PPAT Indonesia, Bandung: PT. Citra Aditya Bakti. 2009.

4 Lumaria L. PERLINDUNGAN HUKUM TERHADAP NOTARIS PASCA BERLAKUNYA UNDANG-UNDANG NOMOR 2 TAHUN TAHUN 2014. CALYPTRA. 2015 Mar 1;4(1):1-4.

5 Erdi E, Perdana S, Suprayitno S. Perlindungan Hukum Terhadap Notaris Dalam Melaksanakan Hak Dan Kewajiban Ingkar Notaris Pada Saat Penyidikan Kepolisian Negara Republik Indonesia. DE LEGA LATA: Jurnal Ilmu Hukum. 2020 Jul 7;5(2):164-82.

6 Rohaya N. Pelarangan Penggunaan Klausula Baku Yang Mengandung Klausula Eksonerasi Dalam Perlindungan Konsumen. Jurnal Hukum Replik. 2018 Mar 1;6(1):23-42.

7 Rizal MS, Yuliati Y, Hamidah S. PERLINDUNGAN HUKUM ATAS DATA PRIBADI BAGI KONSUMEN DALAM KLAUSULA EKSONERASI TRANSPORTASI ONLINE. Legality: Jurnal Ilmiah Hukum. 2019 Jul 22;27(1):68-82.

8 Achmad Y, Mukti Fajar ND. Dualisme Penelitian Hukum Normatif \& Empiris. Yogyakarta, Pustaka Pelajar. 2015

9 Nazir M. MetodePenelitian. Jakarta: Ghalia Indonesia. 1988.

10 Soekanto S. Pengantar Penelitian Hukum, Jakarta. Penerbit Universitas Indonesia. 1981.

11 Arikunto S. Prosedur penelitian suatu pendekatan. Jakarta: Rineka Cipta. 2006.

12 Asikin Z. Amiruddin. Pengantar Metode Penelitian Hukum, Raja Grafindo Persada, Jakarta. 2006.

13 Alwi H. Kamus besar bahasa Indonesia. Jakarta: balai pustaka 2007.

14 Darus BM. Aneka Hukum Bisnis. Bandung: CV Alumni. 1994

15 Darus BM. Kompilasi Hukum Perikatan. Bandung: Citra Aditya Bakti. 2001.

16 Nasution A. Suatu Pengantar: Hukum Perlindungan Konsumen. 2002.

17 Sjahdeni SR. Kebebasan Berkontrak dan Perlindungan yang Seimbang bagi Para pihak dalam perjanjian kredit Bank di Indonesia. 1993
18 Fuady M. Hukum Kontrak (Dari Sudut Pandang Hukum Bisnis) Buku Kedua. Citra Aditya Bakti. Bandung. 2003.

19 Siahaan NH, Sudirman A, Nugroho YW. Hukum konsumen: perlindungan konsumen dan tanggungjawab produk. Panta Rei; 2005.

20 Dan TP. Pengembangan Bahasa, Kamus Besar Bahasa Indonesia. Jakarta: Balai Pustaka. 1990

21 Mahja D. Undang-Undang Nomor 30 Tahun 2004 tentang Jabatan Notaris. Jakarta: Durat Bahagia. 2005.

22 Adjie H. Hukum Notaris Indonesia: Tafsir Tematik Terhadap UU No. 30 Tahun 2004 Tentang Jabatan Notaris. Refika Aditama; 2008.

23 Budiono H. Notaris dan Kode Etiknya, Upgrading dan Refreshing Course Nasional Ikatan Notaris Indonesia.

24 Mertokusumo S. Hukum Acara Perdata Indonesia, Edisi 8 . Yogyakarta. Liberty. 2010.

25 Wiryomartani W. Wawancara via telepon dengan narasumber, 2020.

26 Dhody ARW. Wawancara dengan narasumber, Bangi Kopi Kalimalang, Bekasi, 2020.

27 Richardo H. Wawancara dengan narasumber, Kepolisian Negara Republik Indonesia Daerah Metro Jaya Resort Metropolitan Jakarta Barat, Jakarta, 2020.

28 Riswaji U. Wawancara dengan narasumber, Kepolisian Negara Republik Indonesia Daerah Metro Jaya Resort Metro Bekasi Kota, Kota Bekasi, 2020 